\title{
Dietary Supplement for Core Symptoms of Autism Spectrum Disorder: Where Are We Now and Where Should We Go?
}

\author{
Yong-Jiang $\mathrm{Li}^{1}$, Jian-Jun $\mathrm{Ou}^{2}$, Ya-Min $\mathrm{Li}^{3}$ and Da-Xiong Xiang ${ }^{1 *}$ \\ ${ }^{1}$ Department of Pharmacy, The Second Xiangya Hospital, Central South University, Changsha, China, ${ }^{2}$ Institute of Mental \\ Health, The Second Xiangya Hospital, Central South University, Changsha, China, ${ }^{3}$ Clinical Nursing Teaching and Research \\ Section, The Second Xiangya Hospital, Central South University, Changsha, China
}

OPEN ACCESS

Edited by:

Marin Veldic,

Mayo Clinic,

United States

Reviewed by:

Claudio D'Addario,

Università di Teramo, Italy

Kürşat Altınbaş,

Selçuk University, Turkey

*Correspondence:

Da-Xiong Xiang

xiangdaxiong@163.com

Specialty section:

This article was submitted to

Child and Adolescent Psychiatry,

a section of the journal

Frontiers in Psychiatry

Received: 22 June 2017 Accepted: 08 August 2017

Published: 23 August 2017

Citation:

Li Y Y-J, Ou J-J, Li Y-M and Xiang D-X (2017) Dietary Supplement for Core

Symptoms of Autism Spectrum

Disorder: Where Are We Now and

Where Should We Go?

Front. Psychiatry 8:155.

doi: 10.3389/fpsyt.2017.00155
Autism spectrum disorders (ASDs) are a class of severe and chronic conditions and core symptoms are deficits in social interaction, language communication impairments, and repetitive/stereotyped behavior. Given the limitations of available treatments and substantially increased prevalence of the disease, additional interventions are needed. Since the use of dietary supplements for ASD is of high prevalence, up-to-date information about those supplements are required for both parents and clinicians. Relevant articles were identified through a systematic search of PubMed, EMBASE, Cochrane library, and PsychINFO databases (through May 2017). Current best evidences of 22 randomized controlled trials on 8 different dietary supplements for core symptoms of ASD were reviewed. For each supplement, this report focuses on the definition and potential therapeutic mechanisms, the latest advances, and discussion of study limitations and future directions. Most studies were small and short term, and there is little evidence to support effectiveness of dietary supplements for children with ASD.

Keywords: autism spectrum disorder, behavioral symptoms, dietary supplements, intervention, nutrition

\section{INTRODUCTION}

Autism spectrum disorder (ASD) is defined as a neurodevelopmental condition characterized by social communication impairment, delayed development, social function deficit, and repetitive behavior (1). The substantially increased prevalence of $\operatorname{ASD}(2,3)$ and the associated heavy economic burden (4) provide a strong rationale for developing effective treatment strategies of core symptoms of ASD. To date, no medication is currently available for the core symptoms, and there is an urgent public health need for additional interventions $(5,6)$. While the exact etiology of ASD remains unknown, genetic, neurologic, metabolic, and immunologic factors are involved in the complex pathogenesis $(7,8)$. Besides, studies have observed several nutritional deficient such as vitamin D (9) and omega-3 fatty acids (10) that may occur in children with ASD. This provides a novel strategy (dietary supplements) as a complementary and alternative treatment for ASD.

Feeding problems, such as food selectivity and unusual eating patterns, are of high prevalence in children with ASD (11). Food selectivity has become a concern for its harmful influence in nutrient adequacy and inadequate nutrient intake has been reported to be associated with food selectivity in children with ASD (12). Food selectivity may further result in nutritional deficiency and the impact could be severe (13). Therefore, dietary supplements are widely used to complement 
nutritional deficits in children with ASD. Also, considering the early onset and chronic nature of ASD (14), dietary supplements might be the priority selection for families (15), as it can be early or long-time administrated in younger children, and it is also relatively safe, cheap, effective, and time saving (16). However, family members and caregivers are often hard to have a clear understanding of the safety and potential benefit of those supplements.

During the past years, an increasing number of studies have been conducted for searching and testing novel supplements for ASD and have yielded inconsistent results. But the use of dietary supplements intervention for ASD is of high prevalence (17). Therefore, up-to-date information about those supplements that are being studied are required for both parents and clinicians.

This paper will focus on recent insights into the treatment effects of dietary supplements on core symptoms of ASD (Table 1). For each supplement, this report will summarize the definition and potential therapeutic mechanisms, the latest advances, and discussion of study limitations and future directions. Besides, only findings from randomized controlled trials (RCTs) with rigorous methodology that have used a blind method with appropriate control groups will be discussed, open-label studies were not included in case of significant placebo effect of dietary supplement (18).

\section{METHODS}

A systematic search of PubMed, EMBASE, Cochrane library, and PsycINFO databases was conducted to retrieve studies on dietary supplement interventions for ASD published in the last two decades (through May 2017). The following terms were used: "autism/Autism Spectrum Disorder/autistic/ASD" and “intervention/therapy/treatment/supplement/dietary." Reference lists of selected articles and relevant reviews were also hand searched. Articles were screened and selected according to the following eligibility criteria: (1) the study was a RCT; (2) the study addressed dietary supplements intervention for ASD; (3) outcome of interest was core symptoms of ASD. Our first search provided 6,571 records. After excluding duplicates and records of irrelevant topics, 259 articles remained for full-text review. Papers without original data (e.g., reviews and meta-analyses) and studies not RCTs or not addressed outcome of interest were also excluded. Thus, this filtered search identified 22 articles. The study selection process was presented in Figure 1.

\section{RESULTS}

\section{Methyl B12}

Methyl B12 is a vital cofactor for the regeneration of methionine from homocysteine by providing methyl groups for the transmethylation and transsulfuration metabolic pathways (19, 20). Deficiency of methyl B12 may lead to increased levels of homocysteine and decreased levels of methionine and $S$-adenosylmethionine (SAM) (21-23). SAM deficiency could also restrict the transsulfuration pathway and thus aggravate the accumulation of homocysteine. Furthermore, cysteine and GSH are products of the transsulfuration pathway $(22,23)$, reduced synthesis of them will consequently decrease antioxidant capacity as GSH is a key antioxidant $(24,25)$.

Studies have shown specific deficits in metabolic processes in children with ASD, including both cellular methylation (26) and glutathione-mediated antioxidant defense $(27,28)$. Laboratory changes, including lower plasma methionine, SAM, homocysteine, cystathionine, cysteine, and total glutathione, were also noted in children with $\operatorname{ASD}(26,29)$. Abnormal transsulfuration metabolism and reduced antioxidant capacity were also noted in ASD (30). Therefore, vitamin B12 has been used for elevating methylation capacity and improving the "redox status" of children with ASD. Reversal of those biochemical abnormities by methyl B12 supplementation may improve clinical behavioral outcomes.

Furthermore, vitamin B12 plays as a significant role in inhibiting air pollutant, nitrous oxide $\left(\mathrm{N}_{2} \mathrm{O}\right)$, which was reported as a risk factor for ASD (31). Gestational exposure to $\mathrm{N}_{2} \mathrm{O}$ activates certain opioid receptor subtypes and induces physiological actions that were associated with many known autistic symptoms $(31,32)$. Moreover, $\mathrm{N}_{2} \mathrm{O}$ could oxidize the cobalt ion irreversibly within cobalamin and leave vitamin B12 inactive (33). Therefore, supplementation of vitamin B12 might be of help for the reduced vitamin B12 level and elevated homocysteine levels and other metabolic processes in ASD induced by $\mathrm{N}_{2} \mathrm{O}$ exposure.

Hendren et al. have recently published their findings from a double-blind placebo-controlled trial on 57 children aged 3-7 years with ASD (23). The results showed that methyl B12 supplementation improved symptoms of ASD as the clinician rated Clinical Global Impression Scale of Improvement (CGI-I) score was statistically significantly better (lower) in the methyl B12 group (mean: 2.4) than in the placebo group (mean: 3.1), while no improvement was observed in the parent-rated aberrant behavior checklist (ABC) or Social Responsiveness Scale (SRS). What's more, the better CGI-I score was positively correlated with increased levels of methionine, decreased S-adenosyllhomocysteine $(\mathrm{SAH})$ in plasma, and a better ratio of SAM to $\mathrm{SAH}$, which indicated an improvement in cellular methylation capacity. Those findings were consistent with what reported in their prior published paper of a pilot study using a crossover design (34). Limitations of the two studies were small sample sizes and inadequate laboratory testing.

Methyl B12 supplementation appears to be safe and might be helpful for some symptoms of ASD; however, delivery of methyl B12 in the two trials were subcutaneous injection in every 3 days, and there is no study of oral or nasal administration of methyl B12 on autistic patient. Although subcutaneous injectable methyl B12 appears to be safe and effective, it is also invasive and may be with poor compliance. Oral taken of methyl B12 is considered to be more suitable for dietary supplementation (35), but thought to be less effective because oral absorption does not ensure consistent high concentrations. Further study is required to determine whether methyl B12 could be used as a dietary supplement for ASD.

\section{Vitamin D}

Vitamin D is a kind of steroidal derivatives and is also a neuroactive steroid that involves in the development of brain (36), having 
TABLE 1 | Summary of published randomized controlled trials of dietary supplement interventions for ASD.

\begin{tabular}{|c|c|c|c|c|c|c|c|}
\hline Supplement & Reference & Study design & $\begin{array}{l}\text { Subjects }(N, \text { male } \\
\text { percentage, age } \\
\text { range in years) }\end{array}$ & $\begin{array}{l}\text { Intervention doses and } \\
\text { duration }\end{array}$ & $\begin{array}{l}\text { Behavior outcome } \\
\text { measure }\end{array}$ & Primary results & $\begin{array}{l}\text { Serious } \\
\text { adverse } \\
\text { effects }\end{array}$ \\
\hline \multirow[t]{2}{*}{ Vitamin B12 } & Bertoglio et al. (34) & $\begin{array}{l}\text { Double-blind, placebo- } \\
\text { controlled, crossover }\end{array}$ & 30 (93\%), 3-8 & $\begin{array}{l}64.5 \mu \mathrm{g} / \mathrm{kg} \text { injection, every third } \\
\text { day, crossover } 6 \text { weeks }\end{array}$ & $\begin{array}{l}\text { PIA-CV, CGI-I, CARS, } \\
\text { PPVT-III, Stanford Binet } \\
\text { Fifth Edition Routing } \\
\text { Subsets, ABC, CBCL, } \\
\text { and MCDI }\end{array}$ & $\begin{array}{l}\text { Better CGI-I score, no significant improvement in } \\
\text { other measures }\end{array}$ & None \\
\hline & Hendren et al. (23) & $\begin{array}{l}\text { Double-blind, } \\
\text { placebo-controlled }\end{array}$ & 57 (79\%), 3-7 & $\begin{array}{l}75 \mu \mathrm{g} / \mathrm{kg} \text { injection, every third } \\
\text { day, } 8 \text { weeks }\end{array}$ & CGIII, ABC, SRS & $\begin{array}{l}\text { Better CGI-I score, no improvement in ABC and } \\
\text { SRS }\end{array}$ & None \\
\hline Vitamin D3 & Saad et al. $(48,136)$ & $\begin{array}{l}\text { Double-blind, } \\
\text { placebo-controlled }\end{array}$ & 109 (78\%), 3-10 & $\begin{array}{l}300 \mathrm{IU} \text { vitamin D3/kg/day, } \\
4 \text { months }\end{array}$ & ABC, CARS, ATEC, SRS & Significant improvements in all measures & None \\
\hline \multirow[t]{6}{*}{ Omega-3 fatty acid } & Amminger et al. (101) & $\begin{array}{l}\text { Double-blind, } \\
\text { placebo-controlled }\end{array}$ & 13 (100\%), 5-17 & $\begin{array}{l}840 \mathrm{mg} / \text { day EPA }+700 \mathrm{mg} / \text { day } \\
\text { DHA, } 6 \text { weeks }\end{array}$ & $\mathrm{ABC}$ & No significant improvement in $\mathrm{ABC}$ & None \\
\hline & Yui et al. (105) & $\begin{array}{l}\text { Double-blind, } \\
\text { placebo-controlled }\end{array}$ & 13 (92\%), 6-28 & $\begin{array}{l}120 \text { or } 240 \text { mg/day ARA }+120 \\
\text { or } 240 \text { mg/day DHA, } 16 \text { weeks }\end{array}$ & $A B C, A D I-R, S R S$ & Significant improvement in all measures & None \\
\hline & Bent et al. (103) & $\begin{array}{l}\text { Double-blind, } \\
\text { placebo-controlled }\end{array}$ & 27 (89\%), 3-8 & $\begin{array}{l}0.7 \mathrm{~g} / \text { day EPA }+0.46 \mathrm{~g} / \text { day } \\
\text { DHA, } 12 \text { weeks }\end{array}$ & $\begin{array}{l}\text { ABC PPVT EVT BASC, } \\
\text { SRS CGI-S }\end{array}$ & No significant differences in all measures & None \\
\hline & Bent et al. (104) & $\begin{array}{l}\text { Double-blind, } \\
\text { placebo-controlled }\end{array}$ & 57 (88\%), 5-8 & $\begin{array}{l}0.7 \mathrm{~g} / \text { day EPA }+0.46 \mathrm{~g} / \text { day } \\
\mathrm{DHA}, 12 \text { weeks }\end{array}$ & ABC, SRS, CGI-I & $\begin{array}{l}\text { Significant improvement in stereotypy and } \\
\text { lethargy subscales of ABC, no significant } \\
\text { differences in other measures }\end{array}$ & None \\
\hline & Voigt et al. (106) & $\begin{array}{l}\text { Double-blind, } \\
\text { placebo-controlled }\end{array}$ & 48 (83\%), 3-10 & 200 mg/day DHA, 6 months & CGI-I, ABC, CDI, BASC & $\begin{array}{l}\text { No significant improvement in CGI-I across } \\
\text { groups and in all other measures across groups }\end{array}$ & None \\
\hline & Mankad et al. (102) & $\begin{array}{l}\text { Double-blind, } \\
\text { placebo-controlled }\end{array}$ & $37(73 \%), 2-5$ & $\begin{array}{l}1.5 \mathrm{~g} / \text { day EPA + DHA, } \\
6 \text { months }\end{array}$ & $\begin{array}{l}\text { PDDBI, BASC-2, CGI-I, } \\
\text { VABS-II, PLS-4 }\end{array}$ & No significant improvement in all measures & None \\
\hline \multirow[t]{3}{*}{$\begin{array}{l}\text { Probiotic and digestive } \\
\text { enzyme }\end{array}$} & $\begin{array}{l}\text { Munasinghe } \\
\text { et al. (119) }\end{array}$ & $\begin{array}{l}\text { Double-blind, placebo- } \\
\text { controlled, crossover }\end{array}$ & 43 (84\%), 3-8 & $\begin{array}{l}\text { Proteolytic enzymes: two } \\
\text { caps per meal, max } 9 \text { caps, } \\
\text { crossover } 3 \text { months }\end{array}$ & GBRS & No significant improvement in all measures & None \\
\hline & Parracho et al. (118) & $\begin{array}{l}\text { Double-blind, placebo- } \\
\text { controlled, crossover }\end{array}$ & 22 (91\%), 4-16 & $\begin{array}{l}\text { Probiotics: } 4.5 \times 10^{10} \mathrm{CFU} / \text { day, } \\
\text { crossover } 6 \text { weeks }\end{array}$ & DBC, TBPS & $\begin{array}{l}\text { Significant improvement in TBPS, no } \\
\text { improvement in DBC }\end{array}$ & None \\
\hline & Saad et al. (120) & $\begin{array}{l}\text { Double-blind, } \\
\text { placebo-controlled }\end{array}$ & 101(81\%), 3-9 & Digestive enzyme, 3 months & CARS, GBRS & $\begin{array}{l}\text { Significant improvement in in emotional response, } \\
\text { general impression autistic score of CARS, and in } \\
\text { general behavior and gastrointestinal symptoms } \\
\text { of GBRS }\end{array}$ & None \\
\hline Folinic acid & Frye et al. $(55,58)$ & $\begin{array}{l}\text { Double-blind, } \\
\text { placebo-controlled }\end{array}$ & $\begin{array}{l}48 \text { (82\%), mean } \\
7.3\end{array}$ & $\begin{array}{l}\text { Folinic acid: } 2 \mathrm{mg} / \mathrm{kg} / \text { day, } \max \\
50 \mathrm{mg}, 12 \text { weeks }\end{array}$ & $\begin{array}{l}\text { CELF-preschool-2, } \\
\text { CELF-4, PLS-5, OACIS, } \\
\text { VABS, ABC, SRS, } \\
\text { BASC, AIM, ASQ }\end{array}$ & $\begin{array}{l}\text { Significant improvement in verbal communication, } \\
\text { VABS, ABC, ASQ, BASC, and better for FRAA } \\
\text { positive participants }\end{array}$ & None \\
\hline Camel milk & $\begin{array}{l}\text { Bashir and Al-Ayadhi } \\
\text { (66); AL-Ayadhi and } \\
\text { Elamin (64) }\end{array}$ & $\begin{array}{l}\text { Double-blind, } \\
\text { placebo-controlled }\end{array}$ & 45 (89\%), 2-12 & $500 \mathrm{ml} /$ day, 2 weeks & CARS & $\begin{array}{l}\text { Significant improvement in CARS in raw camel } \\
\text { milk group }\end{array}$ & None \\
\hline
\end{tabular}


TABLE 1 | Continued

\begin{tabular}{|c|c|c|c|c|c|c|c|}
\hline Supplement & Reference & Study design & $\begin{array}{l}\text { Subjects ( } N \text {, male } \\
\text { percentage, age } \\
\text { range in years) }\end{array}$ & $\begin{array}{l}\text { Intervention doses and } \\
\text { duration }\end{array}$ & $\begin{array}{l}\text { Behavior outcome } \\
\text { measure }\end{array}$ & Primary results & $\begin{array}{l}\text { Serious } \\
\text { adverse } \\
\text { effects }\end{array}$ \\
\hline Sulforaphane & Singh et al. (131) & $\begin{array}{l}\text { Double-blind, } \\
\text { placebo-controlled }\end{array}$ & 29 (100\%), 13-27 & 50-150 $\mu \mathrm{mol} /$ day, 18 weeks & $\begin{array}{l}\text { ABC, SRS, CGIII, } \\
\text { OACIS }\end{array}$ & Significant improvement in all measures & None \\
\hline \multirow[t]{5}{*}{ GFCF diet } & Elder et al. (77) & $\begin{array}{l}\text { Double-blind, placebo- } \\
\text { controlled, crossover }\end{array}$ & 15 (80\%), 2-16 & GFCF diet, crossover 6 weeks & CARS, ECO & No significant improvement in all measures & None \\
\hline & Whiteley et al. (74) & Single-blind & 72 (89\%), 4-10 & GFCF diet, 12 months & $\begin{array}{l}\text { ADOS, GARS, VABS, } \\
\text { ADHD-IV }\end{array}$ & No significant improvement in all measures & None \\
\hline & Knivsberg et al. (73) & Single-blind & 20, mean 7.4 & GFCF diet, 12 months & DIPAB & Significant improvement in DIPAB & $\begin{array}{l}\text { Not } \\
\text { reported }\end{array}$ \\
\hline & Johnson et al. (75) & $\begin{array}{l}\text { Single-blind, } \\
\text { placebo-controlled }\end{array}$ & 22 (82\%), 3-5 & GFCF diet, 3 months & $\begin{array}{l}\text { Mullen scales of early } \\
\text { learning AGS edition, } \\
\text { CBCL, direct behavior } \\
\text { observation measure }\end{array}$ & No significant improvement in all measures & None \\
\hline & Hyman et al. (76) & $\begin{array}{l}\text { Double-blind, } \\
\text { placebo-controlled }\end{array}$ & 14 (86\%), 3-5 & GFCF diet, 12 weeks & $\begin{array}{l}\text { RFRLRS, Conner's } \\
\text { Abbreviated Rating } \\
\text { Scale }\end{array}$ & No significant improvement in all measures & None \\
\hline $\begin{array}{l}\text { Gluten and casein } \\
\text { supplementation }\end{array}$ & $\begin{array}{l}\text { Pusponegoro } \\
\text { et al. (78) }\end{array}$ & $\begin{array}{l}\text { Double-blind, } \\
\text { placebo-controlled }\end{array}$ & 50 (88\%), 3-7 & $\begin{array}{l}11 \mathrm{~g} \text { of gluten and } 12 \mathrm{~g} \text { of } \\
\text { casein, } 1 \text { weeks }\end{array}$ & AWPC, PDDBI & No significant improvement in all measures & None \\
\hline
\end{tabular}

ABC, aberrant behavior checklist: ADI-R, Autism Diagnostic Interview-Revised; ADOS, Autism Diagnostic Observation Scale; AWPC, approach withdrawal problems composite; ADHD-IV. Attention-Deficit Hyperactivity Disorder-IV Scale; AIM, autism impact measure; ASQ, Autism Symptoms Questionnaire; ATEC, Autism Treatment Evaluation Checklist; BASC, Behavior Assessment Scale for Children; CBCL, Child Behavior Checklist; CDI, Child Development Inventory; CARS, Childhood Autism Rating Scale; CELF, Clinical Evaluation of Language Fundamentals; CGI-I, Clinical Global Impression Scale of Improvement; DBC, Development Behavior Checklist; DIPAB, Diagnose of Psykotisk Adfaerd hosBørn (Diagnosis of Psychotic Behavior in Children); ECO, Ecological Communication Orientation; EVT, Expressive Vocabulary Test; FRAA, folate receptor- $\alpha$ autoantibody; GARS, Gilliam Autism Rating Scale; GBRS, Global Behavior Rating Scale; MCDI, MacArthur Communication Developmental Inventory; OACIS, Ohio Autism Clinical Impression Scale; PIA-CV, Parent Interview for Autism-Clinical Version; PPVT, Peabody Picture Vocabulary Test; PPVT-III, Peabody Picture Vocabulary Test-Third Edition: PDDBI, Pervasive Developmental Disorders Behavioral Inventory: PLS, Preschool Language Scale: RFRLRS, Ritvo-Freeman Real Life Rating Scales; SRS, Social Responsiveness Scale; TBPS, Total Behavior Problem Score; VABS, Vineland Adaptive Behavior Scale; GFCF, gluten-free and casein-free; ARA, arachidonic acid; DHA, docosahexaenoic acid; EPA, eicosapentaenoic acid. 


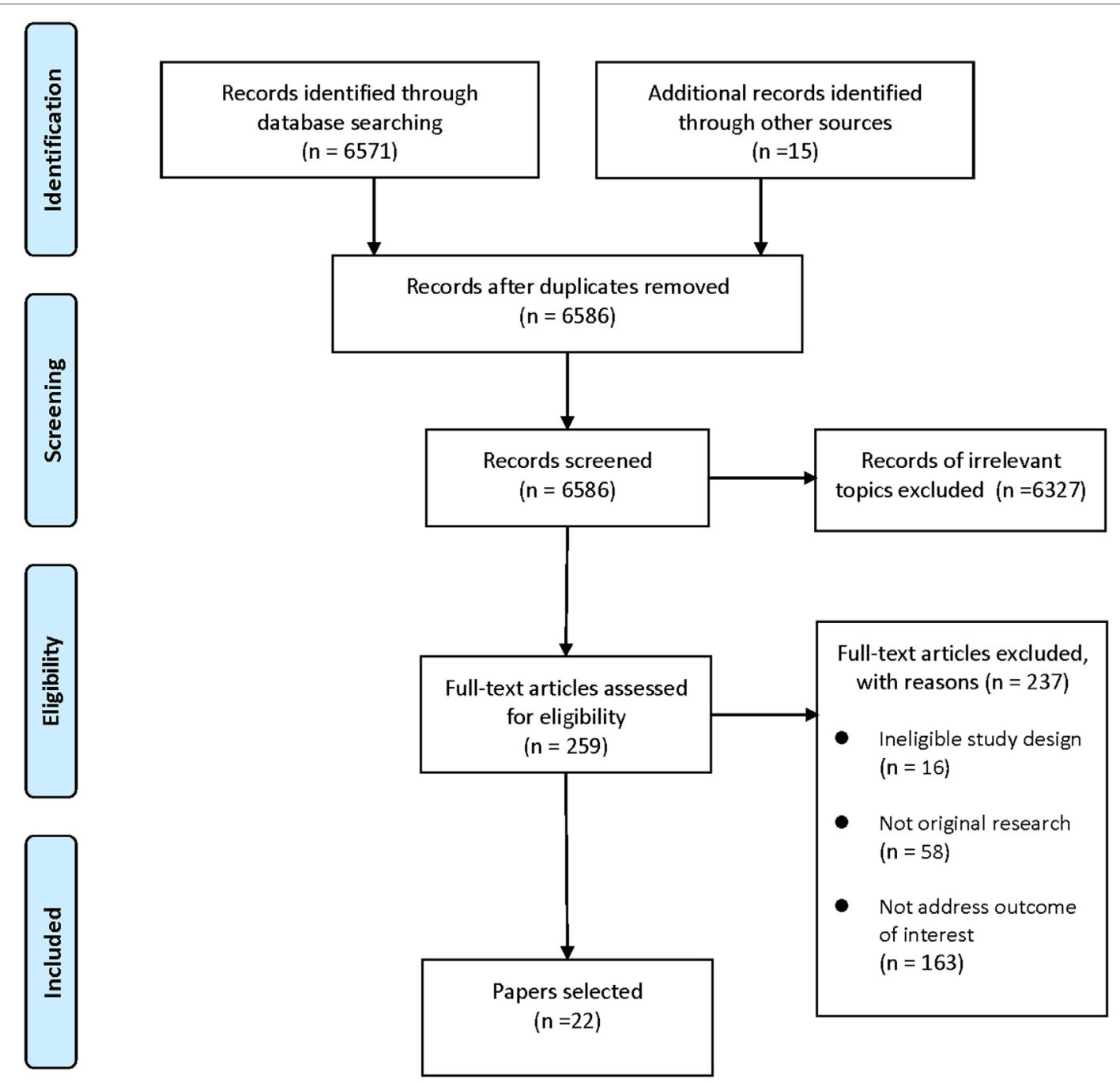

FIGURE 1 | Flow diagram of the study selection process.

multi biological activities, including cellular proliferation, differentiation, calcium signaling, neurotrophic, and neuroprotective actions (9); it also plays an essential role in myelination (37) and thus appears to have effects on neurotransmission and synaptic plasticity $(9,38)$.

Mounting numbers of studies have reported associations of ASD with decreased vitamin D levels in patients $(39,40)$, with decreased maternal vitamin $\mathrm{D}$ levels during pregnancy $(41,42)$ and even with decreased solar ultraviolet exposure (43). Possible mechanisms for vitamin D that helping prevent and treat ASD have been recently comprehensively reviewed $(9,44,45)$. Two explanations are the most proposed. The first is the anti-inflammatory effects of vitamin D in the brain (46), and the second is its effects on serotonin (downregulate peripheral tryptophan hydroxylase 1 and upregulate central tryptophan hydroxylase 2) (47).

Although the association between ASD and vitamin D has been extensively studied, only one RCT has been published (48). This trial included 109 children aged 3-10 years with ASD. The dose of vitamin D was $300 \mathrm{IU} / \mathrm{kg} /$ day, not exceed 5,000 IU/day. After
4 months of supplementation, mean $25(\mathrm{OH}) \mathrm{D}$ in the treatment group was significantly increased, but not in the placebo group. As for behavioral measures, rated scores of ABC, CARS, Autism Treatment Evaluation Checklist, and SRS were all significantly better in children supplemented with vitamin D.

Findings from the only RCT suggested that oral vitamin D supplementation could safely improve $25(\mathrm{OH}) \mathrm{D}$ levels as well as improve core symptoms of ASD. While the data are preliminary, it may be recommended for children with ASD with a dose that works in the trial, especially for autistic patients with vitamin D deficiency.

\section{Folinic Acid}

Folic acid, an essential water-soluble B vitamin, is closely related to the metabolism of homocysteine and glutathione $(48,49)$. As discussed earlier, homocysteine and glutathione abnormalities are associated with ASD. Thus, disruptions in folate-related metabolism may increase the risk of ASD. Several abnormalities in the metabolism of folic acid have been linked to ASD (50), and 
a recent review has evidenced the association between maternal supplementation with folic acid during the pregnancy and decreased risk of ASD in offspring (51).

Folinic acid is a reduced form of folate, intake of folinic acid could normalize folate-dependent one-carbon metabolism that may help stabilize cerebrospinal fluid (CSF) folate concentrations and significantly improve neurological symptoms (52-54). Folinic acid can readily enter the folate cycle without reduction (54). The folate receptor- $\alpha(\mathrm{FR} \alpha)$, which is responsible for transportation of folic acid into the brain, might be blocked in folate receptor- $\alpha$ autoantibody (FRAA)-positive patients or due to mitochondrial dysfunction or genetic mutations $(55,56)$, and thus decrease CSF folate concentrations. However, folinic acid is able to cross the blood-brain barrier through reduced folate carrier, though high-serum concentrations are required because of lower affinity than $\mathrm{FR} \alpha(57)$.

There is no published RCT that has evaluated the effects of folic acid intervention on the treatment of autistic children. However, one recent randomized double-blind placebo-controlled trial has tested high-dose folinic acid for 12 weeks and found significant improvements in verbal communication (58). In that study, 48 children with ASD and language impairment were randomized to receive folinic acid ( $2 \mathrm{mg} / \mathrm{kg} /$ day, maximum $50 \mathrm{mg} /$ day; $n=23$ ) or placebo $(n=25)$. FRAA status of the children was subtyped. The investigators used various outcome measures of verbal communication (CELF, PLS) and behavioral assessment (Ohio Autism Clinical Impression Scale, VABS, ABC, SRS, Behavior Assessment Scale for Children, Autism Impact Measure, and Autism Symptoms Questionnaire) and found significant improvements in verbal communication, and core symptoms of ASD in those receiving folinic acid when compared with those receiving placebo; what's more, the improvements were significantly greater for FRAA-positive participants.

Although folinic acid was well tolerated with very few adverse effects, the sample size was small and treatment duration was not long enough. Since folinic acid may become increasingly used to treat ASD in the future, its safety should be further ensured. Besides, clinicians should be cautious about the interaction of folinic acid and methyl B12 as they are metabolically related $(19,22,59)$.

\section{Camel Milk}

Camel milk, an important source of nutrient in some countries, has a unique composition that differs from other milk. Compared to cow milk, it does not contain beta-casein and beta-lactoglobulin, two powerful allergens (60), and thus makes it a good choice for children suffer from milk allergies $(61,62)$. Furthermore, it also contains various protective proteins, which exert antibacterial (63) and immunological activities (64).

The potential therapeutic potencies of camel milk on autism might be from the inflammation-inhibiting proteins that help rehabilitating the immune system, or from its antibacterial properties that have effects on certain symptoms accompanying autism enterocolitis (65).

There is one double-blind, placebo-controlled trial to evaluate the effects of camel milk therapy among children with an ASD $(64,66)$. In that study, 45 subjects were randomly assigned to receive boiled camel milk $(n=15)$, raw camel milk $(n=15)$, and cow milk as placebo $(n=15)$ for 2 weeks. The amount of milk consumption was $500 \mathrm{ml} /$ day. Investigators observed significantly improved clinical measurements (CARS score) recorded by trained professional and parents of autistic children in raw camel milk group only. Camel milk therapy was generally well tolerated with minimal adverse effects (irritability and stomach discomfort).

Although the results appear to be encouraging, the trial has limitations. Sample size was small; mechanisms was not clear; use of cow milk as placebo was not convincing; and only one behavior measure (CARS scores) was inadequate to comprehensively reveal changes in core symptoms of ASD. The study laid a foundation for further detailed researches.

\section{Gluten and Casein: Free and Supplement}

Gluten-free and casein-free (GFCF) diets implies the elimination of all food items containing cereals such as flours and bread, or containing dairy products such as milk, yogurt, butter, and others.

The opioid theory was the most cited theory for adopting of a CFGF diet for the treatment of $\operatorname{ASD}(67,68)$. It is known that, after digestion, certain types of peptides could cross the intestinal mucosa intact and may further cross the blood-brain barrier through bloodstream transportation and reach the central nervous system even to a high level in the case of impairments in intestinal track or celiac disease (69). There is increasing evidence for a "leaky gut" associated with at least some cases of ASD $(70,71)$. Therefore, digestion of gluten and casein may result in an overload of exogenous neuropeptides, including gluteomorphins and beta-casomorphins (72), which may affect brain functioning as well as produce an opioid-type effect that manifests in the core symptoms commonly observed in ASD.

Six small randomized trials on this topic that has used a blind method have been published. In 2003, Knivsberg et al. published the first randomized, controlled, single-blind study of a GFCF dietary intervention on autistic behavior (73). In their 12 months experimental period on 20 children, significant reduction of autistic behavior, measured by Diagnose of Psykotisk Adfaerd hosBørn, was observed in GFCF diet group, but not in the control group. However, the other two single-blind trials observed no statistically significant differences between treatment groups $(74,75)$. Of the only two double-blind, placebo-controlled studies, one observed for 12 weeks (76) and one used a 6-week crossover design (77), both data did not support statistically significant effects of GFCF dietary on core symptoms of ASD.

By contrast, Pusponegoro et al. conducted a double-blind, placebo-controlled trial to determine the effect of gluten and casein supplementation on symptoms in children with ASD (78). After $11 \mathrm{~g}$ of gluten and $12 \mathrm{~g}$ of casein supplementation for 1 week, mean differences in approach withdrawal problem composite score, a subtest of Pervasive Developmental Disorders Behavioral Inventory, and in the gastrointestinal (GI) symptoms were not significant.

Numerous reviews on this topic have been published, and they all concluded GFCF diet as lack of evidence for improving autistic symptoms $(67,68,79-81)$. Overall, findings from 
current best evidence suggest that GFCF dietary may not help to reduce core symptoms of ASD neither gluten nor casein supplementation increase the symptoms. As GFCF dietary are a special version of common food items that are usually expensive (82), administration of such a diet may place an extra burden on families. Besides, long term following GFCF diet will significantly change the children's eating behavior and can further complicate the social integration of children with $\operatorname{ASD}(83,84)$. Thus, for the treatment of core symptoms of ASD, the GFCF diet is not recommended.

\section{Omega-3 Fatty Acids}

Omega-3 fatty acids are a special group of long-chain polyunsaturated fatty acids that play an important role in normal growth and are essential to neurodevelopment (85-87). The two omega-3 acids that are of interest for supplementation are eicosapentaenoic acid (EPA) and docosahexaenoic acid (DHA) as human body cannot synthesize them and the intake of EPA and DHA are mostly depend on dietary or food supplements (88).

Eicosapentaenoic acid and DHA are substrate for the production of eicosanoids such as prostaglandins (89) which is necessary for cellular communication (90) and immune regulation (91). EPA and DHA are of fundamental importance for brain structure and function because they are orthomolecules and their functional sites are exclusively cell membranes (92). Therefore, DHA and EPA have been studied for the treatment of multiple neurodevelopmental disorders, including $\operatorname{ASD}(93,94)$, ADHD $(95,96)$, schizophrenia (97), and mood disorders (98, 99). Also, reduced concentrations of omega- 3 fatty acids have been observed in children with ASD $(10,100)$, suggesting omega-3 fatty acids supplementation may be of help for the treatment of symptoms associated with ASD.

There have been six double-blind, placebo-controlled trials, with inconsistent results. Amminger et al. (101) observed $840 \mathrm{mg} /$ day EPA + $700 \mathrm{mg} /$ day DHA for 6 weeks compared with placebo was superior over placebo in reducing stereotypy, inappropriate speech and hyperactivity, though their statistical analyses for $\mathrm{ABC}$ subscales indicated no significant differences between treatment groups. In 2015, Mankad et al. (102) published a replication study with the same dose as Amminger et al. and longer duration (12 weeks), but failed to any effect of the supplementation on core symptoms of ASD. In a pilot trial, Bent et al. (103) used $0.7 \mathrm{~g} /$ day EPA + $0.46 \mathrm{~g} /$ day DHA for 12 weeks for the treatment of ASD in 27 children aged 3-8 years, their initial results did not show a statistically significant benefit from omega-3 fatty acids. Several years later, Bent et al. (104) published their new findings from a trial with larger sample size $(n=57)$, they observed a significant improvement in stereotypy and lethargy subscales of $\mathrm{ABC}$, but no significant differences in other measures such as SRS and CGI-I. In another pilot study, Yui et al. (105) used a 12 weeks, $0.24 \mathrm{~g} /$ day DHA + $0.24 \mathrm{~g} /$ day arachidonic acid (ARA) intervention on 13 older ASD patient (age range: 6-28 years). Significant improvements were observed in social withdrawal subscale of $\mathrm{ABC}$, stereotyped and repetitive behavior of Autism Diagnostic Interview-Revised, and communication subscale of SRS, this was the only study that reported significant improvements in all behavior measures. Voigt et al.
(106) measured the effect of long-term (6 months) intake of low dose DHA (200 mg/day) on 48 children with ASD, and they did not find a significant difference in CGI-I or in other measures across groups.

Among the six included RCTs, five showed that omega-3 fatty acid supplementation does not affect core symptoms of ASD in overall measures, and the only study that reported the most significant results was clearly limited in sample size (105). Besides, a recent meta-analysis of five RCTs have assessed the association, and results from their quantitative analyses indicated that there were no statistically significant differences in ASD symptoms between groups measured by validated scales (93).

Currently, limited data suggest that omega-3 fatty acid supplementation may be not effective for the treatment of core symptoms of ASD in children. However, fatty acids were generally safe and were well tolerated in all six trials, and they might still be of benefit for the neurodevelopment in children.

\section{Probiotics and Digestive Enzyme}

Probiotics are microorganisms that are living in intestinal mucosa and are able to increase expression of mucin (107), reduce over growth of bacteria (108), stimulate mucosal immunity $(109,110)$, and synthesize antioxidant substances (111), and thus stabilize the mucosal barrier and improve digestive health $(112,113)$.

Studies reported a high prevalence of various GI disturbances in patients with $\operatorname{ASD}(114,115)$, and there is increasing evidence for a "gut-brain axis" associated with at least some cases of ASD $(116,117)$. Those suggest that the development of treatment strategies that can restore normal gut microbiota, reduce gut production and absorption of toxins, such as dietary supplement of probiotics, may provide an optional strategy that may attenuate behavioral symptoms of ASD by easing GI symptoms.

A double-blind placebo-controlled trial using a crossover design over 12 months on 22 children aged 4-16 years with ASD showed significant improvement in Total Behavior Problem Score, but not in Development Behavior Checklist with daily feeding of $4.5 \times 10^{10} \mathrm{CFU}$ of probiotics (118). While another double-blind placebo-controlled trial (119) using crossover design over 6 months for 43 children aged 3-8 years did not find any clinically significant improvement in all behavioral measures with the Peptizyde ${ }^{\mathrm{TM}}$, a combination of three plant-derived proteolytic enzymes. Saad et al. performed a double-blind RCT on 101 children with ASD aged from 3 to 9 years. Significant improvement in emotional response, general impression autistic score, general behavior, and GI symptoms was observed after 3 months digestive enzyme therapy (120). Samples in those studies were relatively small but not limited to children with GI symptoms. Although probiotics and digestive enzyme treatment of core symptoms of ASD were still inconclusive, they at least did improve the GI health in ASD patients.

Currently, a new RCT using a rigorous control design aimed to determine the role of probiotics on clinical, biochemical, and neurophysiological parameters in ASD children is underway (121). The method protocol used a group of 100 preschoolers with ASD and classified to a GI group or to a non-GI. Findings from this trial could add more information on the effects of treatments with probiotics on children with ASD. 


\section{Sulforaphane (SFN)}

Sulforaphane, an isothiocyanate derived from cruciferous vegetables, is the product of glucoraphanin hydrolysis by myrosinase $(122,123)$. Although the mechanism remains to be clarified, the "fever effect" of ASD that can dramatically but temporarily ameliorate the behavioral symptoms of ASD was reported by parents of children with ASD (124). SFN has metabolic effects that extensively associated with heat shock proteins (125), and thus in some ways resemble that of fever (125). Also, several biological effects of SFN such as against oxidative stress (126), inflammation $(127,128)$, and DNA damage (129), which are potential and prominent mechanistic characteristics of ASD, and its low toxicity (130) and well tolerance premised the test of SFN treatment of ASD.

Singh et al. (131) conducted and reported the first doubleblind, placebo-controlled trial of SFN treatment of ASD on 29 males aged 13-17 years old for 18 weeks and observed significant improvement in all behavioral measures (ABC, SRS, and CGI-I), especially in social interaction and communication. It appears that SFN is safe and effective and might be acceptable for daily supplement. However, participants in this trial were older and were selected because of parental reported history of reduced ASD symptoms during febrile episodes, and participants received an uncharacteristically low placebo effect $(<3.3 \%)$.

A recent review outlined several other ASD-associated basic physiological pathways that can be regulated by SFN, including redox metabolism/oxidative stress, mitochondrial dysfunction, immune dysregulation/neuroinflammation, febrile illness and the heat shock response, and synaptic dysfunction (132). Those pathways may guide further novel treatment strategies for the improvement of core and associated symptoms of ASD. Currently, there are five ongoing trials that are further investigating SFN treatment of ASD (NCT02654743, NCT02909959, NCT02677051, NCT02561481, and NCT02879110). New findings on safety and treatment effect of SFN are gradually to be reported.

\section{DISCUSSION}

While the exact etiology of ASD remains unknown, epidemiological studies have evidenced various risk factors, though none has been proved to be necessary or sufficient alone for developing ASD (133). Large population-based investigations provided novel insights into environmental risk factors for ASD and twin studies served as a unique platform for studying the genetics
(134). The gene-environment interplay is dynamic in autism, and our understanding is still at an early stage. No medication has been shown to reliably improve core symptoms of ASD; however, dietary supplements intervention as a kind of complementary and alternative therapy is widely used. Although, in most cases, dietary supplements are used for the symptoms in children with ASD, and only have a minor role in the treatment of ASD so far, they are potentially effective and might be of help for elucidating the pathogenesis.

Among the eight different supplements reviewed, three (methyl B12, vitamin D3, and omega-3 fatty acids) were guided by deficiencies in ASD; three (folinic acids, probiotics, and CFGF diet) were guided by potential etiological theory and two (camel milk and SFN) were guided by anecdotal evidence. Summarized number of evidence and recommendations were presented in Table 2.

An ideal dietary supplement for children should be safe, easy, cheap, and sensible (135). For safety, all eight different supplementations were generally safe and well tolerated with no report of serious adverse event; for easiness, all eight supplements were easily available and seven could be easily orally administrated, only methyl B12 were injected in current trials and its effect by oral delivery should be further tested; all supplements except GFCF diet were reasonable in price and might be acceptable for families; as for the treatment effect, GFCF diet and ometa- 3 fatty acid were concluded as ineffective on core symptoms of ASD; while vitamin $\mathrm{D}$ is promising and may be recommended for children with ASD; effects of the remaining supplements were inconclusive based on current evidence and further investigations were needed, but folinic acid and SFN were most promising.

It should be noted that the therapeutic effect of some supplements may be only suitable for children with specific conditions. For example, SFN might be more efficacious in children with parental reported history of "fever effect," and the improvements in autistic symptoms after folinic acid supplementation was significantly greater in FRAA-positive patients. Also, it is important to mention that although several dietary supplements may not have benefit in improving core symptoms of ASD, they still could be considered for complementary and alternative treatments for reversing other symptoms such as probiotics for GI symptoms and omega-3 fatty acids for low plasma fatty acid levels in autistic children. Careful examinations should be performed before using dietary supplements as a complementary therapy.

TABLE 2 | Summary of evidence and recommendations.

\begin{tabular}{llll}
\hline Supplement & Number of evidence & Rationale/mechanism & Recommendation \\
\hline Methyl B12 & 2 double-blind RCTs & Correct deficiency & Effectiveness inconclusive but acceptable \\
Vitamin D & 1 double-blind RCT & Correct deficiency & Promising \\
Omega-3 fatty acids & 6 double-blind RCTs & Correct deficiency & Less effective but acceptable \\
Probiotic and digestive enzyme & 3 double-blind RCTs & Ease Gl symptoms & Promising \\
Folinic acid & 1 double-blind RCT & Correct deficiency & Promising \\
Camel milk & 1 double-blind RCT & Improve immune function & Promising \\
& & Ease Gl symptoms & Promising \\
Sulforaphane & 1 double-blind RCT & Fever effect & Not recommend \\
Gluten-free and casein-free diet & 5 double-blind RCTs & Decrease exogenous neuropeptides & \\
\hline
\end{tabular}

Gl, gastrointestinal; $R C T$, randomized controlled trial. 
There are several limitations in our review process. First, the number of included studies was limited. For instance, according to the inclusion criteria, we excluded open-label trials of vitamin D supplementation in case of placebo effect, thus leaving only one RCT included, but there were two open-label trials $(136,137)$. Second, we were unable to perform quantitative analysis of current evidence due to significant heterogeneity in interventions and in outcome measures, thus we only reviewed studies qualitatively. Third, the outcome of interest was limited to core symptoms of ASD, several other supplements used for other aspects of ASD was not considered, such as melatonin, which was used to help autistic children with sleep problems (138).

\section{Future Directions}

- The identification and validation of the cellular targets and mechanisms of supplements are keys for contributing to understanding of their health benefits as well as etiology of ASD.

- Further studies on varied dosages of supplements that are of potential benefits are warranted to maximizing the benefits and minimizing the risk.

- Study durations should be prolonged and sample size should be enlarged as dietary supplements are generally long-time administrated.

\section{REFERENCES}

1. American Psychiatric Association. Diagnostic and Statistical Manual of Mental Disorders $\left(D S M-5^{\varpi}\right)$. Arlington County, VA: American Psychiatric Association Publishing (2013).

2. Christensen DL. Prevalence and characteristics of autism spectrum disorder among children aged 8 years - autism and developmental disabilities monitoring network, 11 sites, United States, 2012. MMWR Surveill Summ (2016) 65:1-23. doi:10.15585/mmwr.ss6503al

3. Zablotsky B, Black LI, Maenner MJ, Schieve LA, Blumberg SJ. Estimated prevalence of autism and other developmental disabilities following questionnaire changes in the 2014 National Health Interview Survey. Natl Health Stat Report (2015) 87:1-20.

4. Lavelle TA, Weinstein MC, Newhouse JP, Munir K, Kuhlthau KA, Prosser LA. Economic burden of childhood autism spectrum disorders. Pediatrics (2014) 133(3):e520-9. doi:10.1542/peds.2013-0763

5. Benevides TW, Carretta HJ, Mandell DS. Differences in perceived need for medical, therapeutic, and family support services among children with ASD. Pediatrics (2016) 137(Suppl 2):S176-85. doi:10.1542/peds.2015-2851P

6. Kalal B, Pai VR, Bhat SS. Autism treatment challenges: need for accelerated research in pharmacological interventions. Clin Biotechnol Microbiol (2016) 1(1):9-10.

7. Packer A. Neocortical neurogenesis and the etiology of autism spectrum disorder. Neurosci Biobehav Rev (2016) 64:185-95. doi:10.1016/j.neubiorev. 2016.03.002

8. Nardone S, Elliott E. The interaction between the immune system and epigenetics in the etiology of autism spectrum disorders. Front Neurosci (2016) 10:329. doi:10.3389/fnins.2016.00329

9. Cannell JJ. Vitamin D and autism, what's new? Rev Endocr Metab Disord (2017) 18(2):183-93. doi:10.1007/s11154-017-9409-0

10. Vancassel S, Durand G, Barthelemy C, Lejeune B, Martineau J, Guilloteau D, et al. Plasma fatty acid levels in autistic children. Prostaglandins Leukot Essent Fatty Acids (2001) 65(1):1-7. doi:10.1054/plef.2001.0281

11. Sharp WG, Berry RC, McCracken C, Nuhu NN, Marvel E, Saulnier CA, et al. Feeding problems and nutrient intake in children with autism spectrum disorders: a meta-analysis and comprehensive review of the literature. J Autism Dev Disord (2013) 43(9):2159-73. doi:10.1007/s10803-013-1771-5
- Reports of anecdotal evidence of treatment effects of novel supplements on symptoms of ASD are encouraged.

\section{CONCLUSION}

To date, most RCTs were limited in small sample sizes and were conducted with various populations and study groups. Many discrepancies and conflicting information in patients must be resolved before recommending a supplement as a safe and effective alternative approach for the treatment of ASD. Clearly, additional clinical trials should be conducted. We believe that a joint effort among basic and clinical researchers and clinicians is paramount to further advance our understanding of the treatment potentials of dietary supplements as well as discovering of novel potent therapeutics.

\section{AUTHOR CONTRIBUTIONS}

Y-JL and D-XX defined the focus of the review. Y-JL and J-JO searched and screened the papers for inclusion. Y-ML summarized included papers. Y-JL drafted the manuscript. All the authors contributed to reviewing the manuscript and read and approved the submitted version.

12. Zimmer MH, Hart LC, Manning-Courtney P, Murray DS, Bing NM Summer S. Food variety as a predictor of nutritional status among children with autism. J Autism Dev Disord (2012) 42(4):549-56. doi:10.1007/ s10803-011-1268-z

13. Ma NS, Thompson C, Weston S. Brief report: scurvy as a manifestation of food selectivity in children with autism. J Autism Dev Disord (2016) 46(4):1464-70. doi:10.1007/s10803-015-2660-x

14. Lai WW, Goh TJ, Oei TP, Sung M. Coping and well-being in parents of children with autism spectrum disorders (ASD). J Autism Dev Disord (2015) 45(8):2582-93. doi:10.1007/s10803-015-2430-9

15. Stewart PA, Hyman SL, Schmidt BL, Macklin EA, Reynolds A, Johnson CR, et al. Dietary supplementation in children with autism spectrum disorders: common, insufficient, and excessive. J Acad Nutr Diet (2015) 115(8):1237-48. doi:10.1016/j.jand.2015.03.026

16. Arnold L, Hurt E, Mayes T, Lofthouse N. Ingestible alternative and complementary treatments for attention-deficit/hyperactivity disorder (ADHD). In: Hoza B, Evans SW, editors. Treating Attention Deficit Disorder. Kingston, NJ: Civic Research Institute (2011). p. 15-1-15-24.

17. Höfer J, Hoffmann F, Bachmann C. Use of complementary and alternative medicine in children and adolescents with autism spectrum disorder: a systematic review. Autism (2017) 21(4):387-402. doi:10.1177/ 1362361316646559

18. Masi A, Lampit A, Glozier N, Hickie I, Guastella A. Predictors of placebo response in pharmacological and dietary supplement treatment trials in pediatric autism spectrum disorder: a meta-analysis. Transl Psychiatry (2015) 5(9):e640. doi:10.1038/tp.2015.143

19. Gok U, Halifeoglu I, Canatan H, Yildiz M, Gursu MF, Gur B. Comparative analysis of serum homocysteine, folic acid and vitamin B 12 levels in patients with noise-induced hearing loss. Auris Nasus Larynx (2004) 31(1):19-22. doi:10.1016/j.anl.2003.09.001

20. Kalinina E, Chernov N, Novichkova M. Role of glutathione, glutathione transferase, and glutaredoxin in regulation of redox-dependent processes. Biochemistry(Mosc)(2014)79(13):1562-83.doi:10.1134/S0006297914130082

21. Ganguly P, Alam SF. Role of homocysteine in the development of cardiovascular disease. Nutr J (2015) 14(1):6. doi:10.1186/1475-2891-14-6

22. Bottiglieri T. Folate, vitamin B 12, and S-adenosylmethionine. Psychiatr Clin North Am (2013) 36(1):1-13. doi:10.1016/j.psc.2012.12.001 
23. Hendren RL, James SJ, Widjaja F, Lawton B, Rosenblatt A, Bent S. Randomized, placebo-controlled trial of methyl B12 for children with autism. J Child Adolesc Psychopharmacol (2016) 26(9):774-83. doi:10.1089/cap.2015. 0159

24. Marí M, Morales A, Colell A, García-Ruiz C, Fernández-Checa JC. Mitochondrial glutathione, a key survival antioxidant. Antioxid Redox Signal (2009) 11(11):2685-700. doi:10.1089/ars.2009.2695

25. Perricone C, De Carolis C, Perricone R. Glutathione: a key player in autoimmunity. Autoimmun Rev (2009) 8(8):697-701. doi:10.1016/j. autrev.2009.02.020

26. James SJ, Cutler P, Melnyk S, Jernigan S, Janak L, Gaylor DW, et al. Metabolic biomarkers of increased oxidative stress and impaired methylation capacity in children with autism. Am J Clin Nutr (2004) 80(6):1611-7.

27. Rose S, Melnyk S, Pavliv O, Bai S, Nick T, Frye R, et al. Evidence of oxidative damage and inflammation associated with low glutathione redox status in the autism brain. Transl Psychiatry (2012) 2(7):e134. doi:10.1038/tp. 2012.61

28. Rose S, Melnyk S, Trusty TA, Pavliv O, Seidel L, Li J, et al. Intracellular and extracellular redox status and free radical generation in primary immune cells from children with autism. Autism Res Treat (2011) 2012:986519. doi:10.1155/2012/986519

29. James SJ, Melnyk S, Fuchs G, Reid T, Jernigan S, Pavliv O, et al. Efficacy of methylcobalamin and folinic acid treatment on glutathione redox status in children with autism. Am J Clin Nutr (2009) 89(1):425-30. doi:10.3945/ ajcn.2008.26615

30. Han Y, Xi QQ, Dai W, Yang SH, Gao L, Su YY, et al. Abnormal transsulfuration metabolism and reduced antioxidant capacity in Chinese children with autism spectrum disorders. Int J Dev Neurosci (2015) 46:27-32. doi:10.1016/j.ijdevneu.2015.06.006

31. Fluegge $\mathrm{K}$. The role of air pollution exposures in mediating nutritional biochemical profiles in autism: a reply to Jory (2015). Nutrition (2016) 32(10):1163. doi:10.1016/j.nut.2016.02.017

32. Quock RM, Best J, Chen D, Vaughn LK, Portoghese P, Takemori A. Mediation of nitrous oxide analgesia in mice by spinal and supraspinal $\kappa$-opioid receptors. Eur J Pharmacol (1990) 175(1):97-100. doi:10.1016/0014-2999(90) 90158-3

33. Flippo TS, Holder WD. Neurologic degeneration associated with nitrous oxide anesthesia in patients with vitamin B12 deficiency. Arch Surg (1993) 128(12):1391-5. doi:10.1001/archsurg.1993.01420240099018

34. Bertoglio K, Jill James S, Deprey L, Brule N, Hendren RL. Pilot study of the effect of methyl B12 treatment on behavioral and biomarker measures in children with autism. J Altern Complement Med (2010) 16(5):555-60. doi:10.1089/acm.2009.0177

35. Andrès E, Fothergill H, Mecili M. Efficacy of oral cobalamin (vitamin B12) therapy. Expert Opin Pharmacother (2010) 11(2):249-56. doi:10.1517/14656560903456053

36. Eyles DW, Burne TH, McGrath JJ. Vitamin D, effects on brain development, adult brain function and the links between low levels of vitamin D and neuropsychiatric disease. Front Neuroendocrinol (2013) 34(1):47-64. doi:10.1016/j.yfrne.2012.07.001

37. Chabas J-F, Stephan D, Marqueste T, Garcia S, Lavaut M-N, Nguyen C, et al. Cholecalciferol (vitamin D 3) improves myelination and recovery after nerve injury. PLoS One (2013) 8(5):e65034. doi:10.1371/journal.pone. 0065034

38. Cui X, Pelekanos M, Liu P-Y, Burne T, McGrath J, Eyles D. The vitamin D receptor in dopamine neurons; its presence in human substantia nigra and its ontogenesis in rat midbrain. Neuroscience (2013) 236:77-87. doi:10.1016/j. neuroscience.2013.01.035

39. Wang T, Shan L, Du L, Feng J, Xu Z, Staal WG, et al. Serum concentration of 25-hydroxyvitamin $\mathrm{D}$ in autism spectrum disorder: a systematic review and meta-analysis. Eur Child Adolesc Psychiatry (2016) 25(4):341-50. doi:10.1007/s00787-015-0786-1

40. Fernell E, Bejerot S, Westerlund J, Miniscalco C, Simila H, Eyles D, et al. Autism spectrum disorder and low vitamin D at birth: a sibling control study. Mol Autism (2015) 6(1):3. doi:10.1186/2040-2392-6-3

41. Grant WB, Soles CM. Epidemiologic evidence for supporting the role of maternal vitamin D deficiency as a risk factor for the development of infantile autism. Dermatoendocrinol (2009) 1(4):223-8. doi:10.4161/derm. 1.4 .9500
42. Vinkhuyzen A, Eyles D, Burne T, Blanken L, Kruithof C, Verhulst F, et al. Gestational vitamin D deficiency and autism-related traits: the generation R study. Mol Psychiatry (2016). doi:10.1038/mp.2016.213

43. Grant WB, Cannell JJ. Autism prevalence in the United States with respect to solar UV-B doses: an ecological study. Dermatoendocrinol (2013) 5(1):159-64. doi:10.4161/derm.22942

44. Ali A, Cui X, Eyles D. Developmental vitamin D deficiency and autism: putative pathogenic mechanisms. J Steroid Biochem Mol Biol (2016). doi:10.1016/j.jsbmb.2016.12.018

45. Cannell JJ, Grant WB. What is the role of vitamin D in autism? Dermatoendocrinol (2013) 5(1):199-204. doi:10.4161/derm.24356

46. Huang Y-N, Ho Y-J, Lai C-C, Chiu C-T, Wang J-Y. 1, 25-Dihydroxyvitamin D 3 attenuates endotoxin-induced production of inflammatory mediators by inhibiting MAPK activation in primary cortical neuron-glia cultures. J Neuroinflammation (2015) 12(1):147. doi:10.1186/s12974-015-0370-0

47. Patrick RP, Ames BN. Vitamin D hormone regulates serotonin synthesis. Part 1: relevance for autism. FASEB J (2014) 28(6):2398-413. doi:10.1096/ fj.13-246546

48. Saad K, Abdel-Rahman AA, Elserogy YM, Al-Atram AA, El-Houfey AA, Othman HA, et al. Randomized controlled trial of vitamin D supplementation in children with autism spectrum disorder. J Child Psychol Psychiatry (2016). doi:10.1111/jcpp.12652

49. Main PA, Angley MT, Thomas P, O’Doherty CE, Fenech M. Folate and methionine metabolism in autism: a systematic review. Am J Clin Nutr (2010) 91(6):1598-620. doi:10.3945/ajcn.2009.29002

50. Castro K, Klein LS, Baronio D, Gottfried C, Riesgo R, Perry IS. Folic acid and autism: what do we know? Nutr Neurosci (2016) 19(7):310-7. doi:10.1179/1 476830514Y.0000000142

51. Gao Y, Sheng C, Xie R-H, Sun W, Asztalos E, Moddemann D, et al. New perspective on impact of folic acid supplementation during pregnancy on neurodevelopment/autism in the offspring children - a systematic review. PLoS One (2016) 11(11):e0165626. doi:10.1371/journal.pone.0165626

52. Karin I, Borggraefe I, Catarino CB, Kuhm C, Hoertnagel K, Biskup S, et al. Folinic acid therapy in cerebral folate deficiency: marked improvement in an adult patient. J Neurol (2017) 264(3):578-82. doi:10.1007/s00415-0168387-6

53. Quijada-Fraile P, O’Callaghan M, Martín-Hernández E, Montero R, GarciaCazorla À, de Aragón AM, et al. Follow-up of folinic acid supplementation for patients with cerebral folate deficiency and Kearns-Sayre syndrome. Orphanet J Rare Dis (2014) 9(1):217. doi:10.1186/s13023-014-0217-2

54. Delmelle F, Thöny B, Clapuyt P, Blau N, Nassogne M-C. Neurological improvement following intravenous high-dose folinic acid for cerebral folate transporter deficiency caused by FOLR-1 mutation. Eur J Paediatr Neurol (2016) 20(5):709-13. doi:10.1016/j.ejpn.2016.05.021

55. Frye RE, Delhey L, Slattery J, Tippett M, Wynne R, Rose S, et al. Blocking and binding folate receptor alpha autoantibodies identify novel autism spectrum disorder subgroups. Front Neurosci (2016) 10:80. doi:10.3389/ fnins.2016.00080

56. Chen C, Ke J, Zhou XE, Yi W, Brunzelle JS, Li J, et al. Structural basis for molecular recognition of folic acid by folate receptors. Nature (2013) 500(7463):486-9. doi:10.1038/nature12327

57. Frye R, Sequeira J, Quadros E, James S, Rossignol D. Cerebral folate receptor autoantibodies in autism spectrum disorder. Mol Psychiatry (2013) 18(3):369-81. doi:10.1038/mp.2011.175

58. Frye R, Slattery J, Delhey L, Furgerson B, Strickland T, Tippett M, et al. Folinic acid improves verbal communication in children with autism and language impairment: a randomized double-blind placebo-controlled trial. Mol Psychiatry (2016). doi:10.1038/mp.2016.168

59. Reynolds E. Vitamin B12, folic acid, and the nervous system. Lancet Neurol (2006) 5(11):949-60. doi:10.1016/S1474-4422(06)70598-1

60. Mäkinen-Kiljunen S, Palosuo T. A sensitive enzyme-linked immunosorbent assay for determination of bovine $\beta$-lactoglobulin in infant feeding formulas and in human milk. Allergy (1992) 47(4):347-52. doi:10.1111/j. 1398-9995.1992.tb02070.x

61. Shabo Y, Barzel R, Margoulis M, Yagil R. Camel milk for food allergies in children. Isr Med Assoc J (2005) 7(12):796-8.

62. Ehlayel MS, Hazeima KA, Al-Mesaifri F, Bener A, editors. Camel milk: an alternative for cow's milk allergy in children. Allergy Asthma Proc (2011) 32(3):255-8. doi:10.2500/aap.2011.32.3429 
63. El Sayed I, Ruppanner R, Ismail A, Champagne CP, Assaf R. Antibacterial and antiviral activity of camel milk protective proteins. J Dairy Res (1992) 59(02):169-75. doi:10.1017/S0022029900030417

64. Al-Ayadhi LY, Elamin NE. Camel milk as a potential therapy as an antioxidant in autism spectrum disorder (ASD). Evid Based Complement Alternat Med (2013) 2013:602834. doi:10.1155/2013/602834

65. Shabo Y, Yagil R. Etiology of autism and camel milk as therapy. Int J Disabil Hum Dev (2005) 4(2):67. doi:10.1515/IJDHD.2005.4.2.67

66. Bashir S, Al-Ayadhi LY. Effect of camel milk on thymus and activationregulated chemokine in autistic children: double-blind study. Pediatr Res (2013) 75(4):559-63. doi:10.1038/pr.2013.248

67. Marí-Bauset S, Zazpe I, Mari-Sanchis A, Llopis-González A, Morales-SuárezVarela M. Evidence of the gluten-free and casein-free diet in autism spectrum disorders: a systematic review. J Child Neurol (2014) 29(12):1718-27. doi:10.1177/0883073814531330

68. Elder JH, Kreider CM, Schaefer NM, de Laosa MB. A review of gluten- and casein-free diets for treatment of autism: 2005-2015. Nutr Diet Suppl (2015) 7:87-101. doi:10.2147/NDS.S74718

69. Daniel H. Molecular and integrative physiology of intestinal peptide transport. Annu Rev Physiol (2004) 66:361-84. doi:10.1146/annurev. physiol.66.032102.144149

70. Ibrahim SH, Voigt RG, Katusic SK, Weaver AL, Barbaresi WJ. Incidence of gastrointestinal symptoms in children with autism: a population-based study. Pediatrics (2009) 124(2):680-6. doi:10.1542/peds.2008-2933

71. Mouridsen S-E, Rich B, Isager T. A longitudinal study of gastrointestinal diseases in individuals diagnosed with infantile autism as children. Child Care Health Dev (2010) 36(3):437-43. doi:10.1111/j.1365-2214.2009.01021.x

72. Janecka A, Staniszewska R, Gach K, Fichna J. Enzymatic degradation of endomorphins. Peptides (2008) 29(11):2066-73. doi:10.1016/j. peptides.2008.07.015

73. Knivsberg A-M, Reichelt K-L, Høien T, Nødland M. Effect of a dietary intervention on autistic behavior. Focus Autism Other Dev Disabl (2003) 18(4):248-57. doi:10.1177/10883576030180040601

74. Whiteley P, Haracopos D, Knivsberg A-M, Reichelt KL, Parlar S, Jacobsen J, et al. The ScanBrit randomised, controlled, single-blind study of a gluten-and casein-free dietary intervention for children with autism spectrum disorders. Nutr Neurosci (2010) 13(2):87-100. doi:10.1179/14768 3010X12611460763922

75. Johnson CR, Handen BL, Zimmer M, Sacco K, Turner K. Effects of gluten free/casein free diet in young children with autism: a pilot study. J Dev Phys Disabil (2011) 23(3):213-25. doi:10.1007/s10882-010-9217-x

76. Hyman SL, Stewart PA, Foley J, Peck R, Morris DD, Wang H, et al. The gluten-free/casein-free diet: a double-blind challenge trial in children with autism. JAutism Dev Disord (2016) 46(1):205-20. doi:10.1007/ s10803-015-2564-9

77. Elder JH, Shankar M, Shuster J, Theriaque D, Burns S, Sherrill L. The gluten-free, casein-free diet in autism: results of a preliminary double blind clinical trial. J Autism Dev Disord (2006) 36(3):413-20. doi:10.1007/ s10803-006-0079-0

78. Pusponegoro HD, Ismael S, Firmansyah A, Sastroasmoro S, Vandenplas Y. Gluten and casein supplementation does not increase symptoms in children with autism spectrum disorder. Acta Paediatr (2015) 104(11):e500-5. doi:10.1111/apa.13108

79. Millward C, Ferriter M, Calver S, Connell-Jones G. Gluten-and casein-free diets for autistic spectrum disorder. Cochrane Database Syst Rev (2008) 2: CD003498. doi:10.1002/14651858.CD003498.pub3

80. Mulloy A, Lang R, O’Reilly M, Sigafoos J, Lancioni G, Rispoli M. Glutenfree and casein-free diets in the treatment of autism spectrum disorders: a systematic review. Res Autism Spectr Disord (2010) 4(3):328-39. doi:10.1016/j. rasd.2009.10.008

81. Mulloy A, Lang R, O’Reilly M, Sigafoos J, Lancioni G, Rispoli M. Addendum to "gluten-free and casein-free diets in treatment of autism spectrum disorders: a systematic review". Res Autism Spectr Disord (2011) 5(1):86-8. doi:10.1016/j.rasd.2010.07.004

82. Lee A, Ng D, Zivin J, Green P. Economic burden of a gluten-free diet. J Hum Nutr Diet (2007) 20(5):423-30. doi:10.1111/j.1365-277X.2007.00763.x

83. Francis K. Autism interventions: a critical update. Dev Med Child Neurol (2005) 47(07):493-9. doi:10.1111/j.1469-8749.2005.tb01178.x
84. Cornish E. Gluten and casein free diets in autism: a study of the effects on food choice and nutrition. J Hum Nutr Diet (2002) 15(4):261-9. doi:10.1046/j. 1365-277X.2002.00372.x

85. Gow RV, Hibbeln JR. Omega-3 fatty acid and nutrient deficits in adverse neurodevelopment and childhood behaviors. Child Adolesc Psychiatr Clin N Am (2014) 23(3):555-90. doi:10.1016/j.chc.2014.02.002

86. McNamara RK, Carlson SE. Role of omega-3 fatty acids in brain development and function: potential implications for the pathogenesis and prevention of psychopathology. Prostaglandins Leukot Essent Fatty Acids (2006) 75(4):329-49. doi:10.1016/j.plefa.2006.07.010

87. Shulkin ML, Pimpin L, Bellinger D, Kranz S, Duggan C, Fawzi W, et al. Effects of omega-3 supplementation during pregnancy and youth on neurodevelopment and cognition in childhood: a systematic review and meta-analysis. FASEB J (2016) 30(1 Suppl):295.5.

88. Simopoulos AP. Genetic variants in the metabolism of omega- 6 and omega- 3 fatty acids: their role in the determination of nutritional requirements and chronic disease risk. Exp Biol Med (2010) 235(7):785-95. doi:10.1258/ ebm.2010.009298

89. Bell J, MacKinlay E, Dick J, MacDonald D, Boyle R, Glen A. Essential fatty acids and phospholipase A 2 in autistic spectrum disorders. Prostaglandins Leukot Essent Fatty Acids (2004) 71(4):201-4. doi:10.1016/j.plefa.2004.03.008

90. Quan N, Banks WA. Brain-immune communication pathways. Brain Behav Immun (2007) 21(6):727-35. doi:10.1016/j.bbi.2007.05.005

91. Kalinski P. Regulation of immune responses by prostaglandin E2. J Immunol (2012) 188(1):21-8. doi:10.4049/jimmunol.1101029

92. Yehuda S, Rabinovitz S, Mostofsky D. Essential fatty acids and the brain: from infancy to aging. Neurobiol Aging (2005) 26(1):98-102. doi:10.1016/j. neurobiolaging.2005.09.013

93. Horvath A, Łukasik J, Szajewska H. $\omega-3$ fatty acid supplementation does not affect autism spectrum disorder in children: a systematic review and meta-analysis. J Nutr (2017) 147(3):367-76. doi:10.3945/jn.116.242354

94. Mazahery H, Stonehouse W, Delshad M, Kruger MC, Conlon CA, Beck KL, et al. Relationship between long chain n-3 polyunsaturated fatty acids and autism spectrum disorder: systematic review and meta-analysis of casecontrol and randomised controlled trials. Nutrients (2017) 9(2):155. doi:10.3390/nu9020155

95. Sonuga-Barke EJ, Brandeis D, Cortese S, Daley D, Ferrin M, Holtmann M, et al. Nonpharmacological interventions for ADHD: systematic review and meta-analyses of randomized controlled trials of dietary and psychological treatments. Am J Psychiatry (2013) 170(3):275-89. doi:10.1176/ appi.ajp.2012.12070991

96. Puri BK, Martins JG. Which polyunsaturated fatty acids are active in children with attention-deficit hyperactivity disorder receiving PUFA supplementation? A fatty acid validated meta-regression analysis of randomized controlled trials. Prostaglandins Leukot Essent Fatty Acids (2014) 90(5):179-89. doi:10.1016/j.plefa.2014.01.004

97. Chen AT, Chibnall JT, Nasrallah HA. A meta-analysis of placebo-controlled trials of omega-3 fatty acid augmentation in schizophrenia: possible stage-specific effects. Ann Clin Psychiatry (2016) 27(4):289-96.

98. Grosso G, Pajak A, Marventano S, Castellano S, Galvano F, Bucolo C, et al. Role of omega-3 fatty acids in the treatment of depressive disorders: a comprehensive meta-analysis of randomized clinical trials. PLoS One (2014) 9(5):e96905. doi:10.1371/journal.pone.0096905

99. Cooper RE, Tye C, Kuntsi J, Vassos E, Asherson P. The effect of omega-3 polyunsaturated fatty acid supplementation on emotional dysregulation, oppositional behaviour and conduct problems in ADHD: a systematic review and meta-analysis. J Affect Disord (2016) 190:474-82. doi:10.1016/j.jad.2015.09.053

100. Meguid NA, Atta HM, Gouda AS, Khalil RO. Role of polyunsaturated fatty acids in the management of Egyptian children with autism. Clin Biochem (2008) 41(13):1044-8. doi:10.1016/j.clinbiochem.2008.05.013

101. Amminger GP, Berger GE, Schäfer MR, Klier C, Friedrich $M H$, Feucht M. Omega-3 fatty acids supplementation in children with autism: a double-blind randomized, placebo-controlled pilot study. Biol Psychiatry (2007) 61(4):551-3. doi:10.1016/j.biopsych.2006.05.007

102. Mankad D, Dupuis A, Smile S, Roberts W, Brian J, Lui T, et al. A randomized, placebo controlled trial of omega- 3 fatty acids in the treatment of young children with autism. Mol Autism (2015) 6(1):18. doi:10.1186/s13229-0150010-7 
103. Bent S, Bertoglio K, Ashwood P, Bostrom A, Hendren RL. A pilot randomized controlled trial of omega- 3 fatty acids for autism spectrum disorder. J Autism Dev Disord (2011) 41(5):545-54. doi:10.1007/s10803-010-1078-8

104. Bent S, Hendren RL, Zandi T, Law K, Choi J-E, Widjaja F, et al. Internetbased, randomized, controlled trial of omega-3 fatty acids for hyperactivity in autism. J Am Acad Child Adolesc Psychiatry (2014) 53(6):658-66. doi:10.1016/j.jaac.2014.01.018

105. Yui K, Koshiba M, Nakamura S, Kobayashi Y. Effects of large doses of arachidonic acid added to docosahexaenoic acid on social impairment in individuals with autism spectrum disorders: a double-blind, placebo-controlled, randomized trial. J Clin Psychopharmacol (2012) 32(2):200-6. doi:10.1097/ JCP.0b013e3182485791

106. Voigt RG, Mellon MW, Katusic SK, Weaver AL, Matern D, Mellon B, et al. Dietary docosahexaenoic acid supplementation in children with autism. J Pediatr Gastroenterol Nutr (2014) 58(6):715-22. doi:10.1097/MPG. 000000000000260

107. Caballero-Franco C, Keller K, De Simone C, Chadee K. The VSL\# 3 probiotic formula induces mucin gene expression and secretion in colonic epithelial cells. Am J Physiol Gastrointest Liver Physiol (2007) 292(1):G315-22. doi:10.1152/ajpgi.00265.2006

108. Quigley EM, Quera R. Small intestinal bacterial overgrowth: roles of antibiotics, prebiotics, and probiotics. Gastroenterology (2006) 130(2):S78-90. doi:10.1053/j.gastro.2005.11.046

109. Pagnini C, Saeed R, Bamias G, Arseneau KO, Pizarro TT, Cominelli F. Probiotics promote gut health through stimulation of epithelial innate immunity. Proc Natl Acad Sci U S A (2010) 107(1):454-9. doi:10.1073/ pnas. 0910307107

110. Ashraf R, Shah NP. Immune system stimulation by probiotic microorganisms. Crit Rev Food Sci Nutr (2014) 54(7):938-56. doi:10.1080/10408398.2 011.619671

111. Amaretti A, Di Nunzio M, Pompei A, Raimondi S, Rossi M, Bordoni A. Antioxidant properties of potentially probiotic bacteria: in vitro and in vivo activities. Appl Microbiol Biotechnol (2013) 97(2):809-17. doi:10.1007/ s00253-012-4241-7

112. Ohland CL, MacNaughton WK. Probiotic bacteria and intestinal epithelial barrier function. Am J Physiol Gastrointest Liver Physiol (2010) 298(6): G807-19. doi:10.1152/ajpgi.00243.2009

113. del Campo R, Garriga M, Pérez-Aragón A, Guallarte P, Lamas A, Máiz L, et al. Improvement of digestive health and reduction in proteobacterial populations in the gut microbiota of cystic fibrosis patients using a Lactobacillus reuteri probiotic preparation: a double blind prospective study. J Cyst Fibros (2014) 13(6):716-22. doi:10.1016/j.jcf.2014.02.007

114. McElhanon BO, McCracken C, Karpen S, Sharp WG. Gastrointestinal symptoms in autism spectrum disorder: a meta-analysis. Pediatrics (2014) 133(5):872-83. doi:10.1542/peds.2013-3995

115. Chaidez V, Hansen RL, Hertz-Picciotto I. Gastrointestinal problems in children with autism, developmental delays or typical development. J Autism Dev Disord (2014) 44(5):1117-27. doi:10.1007/s10803-013-1973-x

116. van De Sande MM, van Buul VJ, Brouns FJ. Autism and nutrition: the role of the gut-brain axis. Nutr Res Rev (2014) 27(02):199-214. doi:10.1017/ S0954422414000110

117. Li Q, Zhou J-M. The microbiota-gut-brain axis and its potential therapeutic role in autism spectrum disorder. Neuroscience (2016) 324:131-9. doi:10.1016/j.neuroscience.2016.03.013

118. Parracho HM, Gibson GR, Knott F, Bosscher D, Kleerebezem M, McCartney AL. A double-blind, placebo-controlled, crossover-designed probiotic feeding study in children diagnosed with autistic spectrum disorders. Int J Probiotics Prebiotics (2010) 5(2):69.

119. Munasinghe SA, Oliff C, Finn J, Wray JA. Digestive enzyme supplementation for autism spectrum disorders: a double-blind randomized controlled trial. J Autism Dev Disord (2010) 40(9):1131-8. doi:10.1007/s10803-010-0974-2

120. Saad K, Eltayeb AA, Mohamad IL, Al-Atram AA, Elserogy Y, Bjørklund G, et al. A randomized, placebo-controlled trial of digestive enzymes in children with autism spectrum disorders. Clin Psychopharmacol Neurosci (2015) 13(2):188. doi:10.9758/cpn.2015.13.2.188

121. Santocchi E, Guiducci L, Fulceri F, Billeci L, Buzzigoli E, Apicella F, et al. Gut to brain interaction in autism spectrum disorders: a randomized controlled trial on the role of probiotics on clinical, biochemical and neurophysiological parameters. BMCPsychiatry (2016) 16(1):183. doi:10.1186/s12888-016-0887-5
122. Higdon JV, Delage B, Williams DE, Dashwood RH. Cruciferous vegetables and human cancer risk: epidemiologic evidence and mechanistic basis. Pharmacol Res (2007) 55(3):224-36. doi:10.1016/j.phrs.2007.01.009

123. Matusheski NV, Jeffery EH. Comparison of the bioactivity of two glucoraphanin hydrolysis products found in broccoli, sulforaphane and sulforaphane nitrile. J Agric Food Chem (2001) 49(12):5743-9. doi:10.1021/jf010809a

124. Curran LK, Newschaffer CJ, Lee L-C, Crawford SO, Johnston MV, Zimmerman AW. Behaviors associated with fever in children with autism spectrum disorders. Pediatrics (2007) 120(6):e1386-92. doi:10.1542/ peds.2007-0360

125. Gan N, Wu Y-C, Brunet M, Garrido C, Chung F-L, Dai C, et al. Sulforaphane activates heat shock response and enhances proteasome activity through up-regulation of Hsp27. J Biol Chem (2010) 285(46):35528-36. doi:10.1074/ jbc.M110.152686

126. Guerrero-Beltrán CE, Calderón-Oliver M, Pedraza-Chaverri J, Chirino YI. Protective effect of sulforaphane against oxidative stress: recent advances. Exp Toxicol Pathol (2012) 64(5):503-8. doi:10.1016/j.etp.2010.11.005

127. Holloway PM, Gillespie S, Becker F, Vital SA, Nguyen V, Alexander JS, et al. Sulforaphane induces neurovascular protection against a systemic inflammatory challenge via both Nrf2-dependent and independent pathways. Vascul Pharmacol (2016) 85:29-38. doi:10.1016/j.vph.2016.07.004

128. Sun C-C, Li S-J, Yang C-L, Xue R-L, Xi Y-Y, Wang L, et al. Sulforaphane attenuates muscle inflammation in dystrophin-deficient $\mathrm{mdx}$ mice via NF-E2-related factor 2 (Nrf2)-mediated inhibition of NF- $\mathrm{kB}$ signaling pathway. J Biol Chem (2015) 290(29):17784-95. doi:10.1074/jbc.M115. 655019

129. Zhang Y, Kensler TW, Cho C-G, Posner GH, Talalay P. Anticarcinogenic activities of sulforaphane and structurally related synthetic norbornyl isothiocyanates. Proc Natl Acad Sci U S A (1994) 91(8):3147-50. doi:10.1073/ pnas.91.8.3147

130. Fahey JW, Kensler TW. Health span extension through green chemoprevention. Virtual Mentor (2013) 15(4):311. doi:10.1001/virtualmentor. 2013.15.4.stas1-1304

131. Singh K, Connors SL, Macklin EA, Smith KD, Fahey JW, Talalay P, et al. Sulforaphane treatment of autism spectrum disorder (ASD). Proc Natl Acad Sci U S A (2014) 111(43):15550-5. doi:10.1073/pnas.1416940111

132. Liu H, Talalay P, Fahey JW. Biomarker-guided strategy for treatment of autism spectrum disorder (ASD). CNS Neurol Disord Drug Targets (2016) 15(5):602-13. doi:10.2174/1871527315666160413120414

133. Lai MC, Lombardo MV, Baron-Cohen S. Autism. Lancet (2014) 383(9920):896-910. doi:10.1016/S0140-6736(13)61539-1

134. Modabbernia A, Velthorst E, Reichenberg A. Environmental risk factors for autism: an evidence-based review of systematic reviews and meta-analyses. Mol Autism (2017) 8(1):13. doi:10.1186/s13229-017-0121-4

135. Arnold LE, Hurt E, Lofthouse N. Attention-deficit/hyperactivity disorder: dietary and nutritional treatments. Child Adolesc Psychiatr Clin N Am (2013) 22(3):381-402. doi:10.1016/j.chc.2013.03.001

136. Saad K, Abdel-rahman AA, Elserogy YM, Al-Atram AA, Cannell JJ, Bjørklund G, et al. Vitamin D status in autism spectrum disorders and the efficacy of vitamin D supplementation in autistic children. Nutr Neurosci (2016) 19(8):346-51. doi:10.1179/1476830515Y.0000000019

137. Feng J, Shan L, Du L, Wang B, Li H, Wang W, et al. Clinical improvement following vitamin D3 supplementation in autism spectrum disorder. Nutr Neurosci (2017) 20(5):284-90. doi:10.1080/1028415X.2015.1123847

138. Cuomo BM, Vaz S, Lee EAL, Thompson C, Rogerson JM, Falkmer T. Effectiveness of sleep-based interventions for children with autism spectrum disorder: a meta-synthesis. Pharmacotherapy (2017) 37(5):555-78. doi:10.1002/phar.1920

Conflict of Interest Statement: The authors declare that the research was conducted in the absence of any commercial or financial relationships that could be construed as a potential conflict of interest.

Copyright $\odot 2017 \mathrm{Li}, \mathrm{Ou}$, Li and Xiang. This is an open-access article distributed under the terms of the Creative Commons Attribution License (CC BY). The use, distribution or reproduction in other forums is permitted, provided the original author(s) or licensor are credited and that the original publication in this journal is cited, in accordance with accepted academic practice. No use, distribution or reproduction is permitted which does not comply with these terms. 